\title{
Mathematical Analysis of the Effect of Iron and Silica on the Reduction Performance of Manganese Ores
}

\author{
S. Ghali ${ }^{1}$ and E. A. Mousa ${ }^{2}$ \\ ${ }^{1}$ Steel and Ferroalloys Department, Central Metallurgical Research and Development Institute (CMRDI), P.O. Box 87, \\ El-Felezzat Street 1, El-Tebbin, Helwan, Cairo 11422, Egypt \\ ${ }^{2}$ Pyrometallurgy Department, Central Metallurgical Research and Development Institute (CMRDI), P.O. Box 87, \\ El-Felezzat Street 1, El-Tebbin, Helwan, Cairo 11422, Egypt \\ Correspondence should be addressed to E. A. Mousa; mousa71@yahoo.com
}

Received 30 September 2014; Revised 17 December 2014; Accepted 18 December 2014

Academic Editor: Sunghak Lee

Copyright (C) 2015 S. Ghali and E. A. Mousa. This is an open access article distributed under the Creative Commons Attribution License, which permits unrestricted use, distribution, and reproduction in any medium, provided the original work is properly cited.

In the current study, a factorial design is used to investigate the effect of total iron and silica on the metallurgical performance of different grades of manganese ores. The derived mathematical formulations are applied to estimate the reduction disintegration index $\left(\mathrm{RDI}_{+6.3}, \mathrm{RDI}_{+3.15}\right.$, and $\left.\mathrm{RDI}_{-0.5}\right)$, reduction index (total reduction index (RIT), manganese reduction index (RIM), and iron reduction index (RIF)), and softening-melting property (start of softening $\left(T_{S 1}\right)$, end of softening $\left(T_{S 2}\right)$, start of melting $\left(T_{m 1}\right)$, and end of melting $\left(T_{m 2}\right)$ ) of manganese ores. The $\mathrm{RDI}_{+6.3}$ and $\mathrm{RDI}_{+3.15}$ are increased with the individual effect of $\mathrm{SiO}_{2}$ and the interaction effect of iron with silica, while they are decreased as the total iron increased. The high-Fe high-SiO ${ }_{2}$ manganese ore showed the highest RIT and RIF. The RIM was almost identical in all manganese ores. The presence of high content of $\mathrm{SiO}_{2}$ resulted in a narrow softening range $\left(62-83^{\circ} \mathrm{C}\right)$, while the high- $\mathrm{Fe}$ high- $\mathrm{SiO}_{2}$ manganese ore exhibited a wider softening range $\left(135-140^{\circ} \mathrm{C}\right)$. The melting range was very small in high- $\mathrm{Fe}$ low- $\mathrm{SiO}_{2}\left(3-16^{\circ} \mathrm{C}\right)$ and high- $\mathrm{Fe}$ high-SiO $\mathrm{S}_{2}\left(6-8^{\circ} \mathrm{C}\right)$ manganese ores, while the low-Fe low- $\mathrm{SiO}_{2}$ manganese ore showed wider melting range $\left(72-74^{\circ} \mathrm{C}\right)$. The derived mathematical models are in a good agreement with the experimental results. The calculations are carried out using Matlab program.

\section{Introduction}

Manganese is considered to be one of the most important alloying elements in different grades of steel and cast iron. Manganese improves the tensile strength, machinability, toughness, hardness, and abrasion resistance of steel. In addition, manganese has favourable influence on forging, welding, and grain refining properties in steel casting. Manganese can be used for production of less expensive austenitic steel grades by replacing the expensive alloying elements such as nickel [1-4]. Moreover, manganese is important to control the sulfur content control in steel and it is commonly used as oxidizers of molten steels [5]. Manganese is usually added in the form of ferromanganese (FeMn) to steel during its treatment in the ladle furnace. About $90-95 \%$ of manganese production is used in steelmaking in the form of alloys such as ferromanganese and silicomanganese while $\sim 30 \%$ of manganese production is used for desulfurization and deoxidation of steel while the other $70 \%$ of manganese is used purely as alloying element in steel [6]. Ferromanganese alloy is relatively expensive because it is produced by carbothermic reduction of manganese ores in the submerged electric arc furnace (SAF) which is highly energy consuming $[7,8]$. Energy input to SAF for production of high carbon ferromanganese (HC FeMn) is $18400-24000 \mathrm{MJ} /$ ton, including $300-360 \mathrm{~kg}$ of fixed carbon and $2400-3400 \mathrm{kWh}$ electrical power [9]. In addition, fluxing materials (e.g., limestone and dolomite) are usually added in amount of $200-450 \mathrm{~kg} /$ ton HC FeMn to adjust the basicity of slag [10]. Smelting reduction processes require relatively high temperature $\left(\sim 1500^{\circ} \mathrm{C}\right)$ for production of $\mathrm{HC}$ FeMn and higher temperature (above $1600^{\circ} \mathrm{C}$ ) is required for silicomanganese (SiMn) production. Manganese ores are commonly contaminated with many impurities (e.g., $\mathrm{Fe}_{2} \mathrm{O}_{3}, \mathrm{SiO}_{2}, \mathrm{CaO}, \mathrm{Al}_{2} \mathrm{O}_{3}$, P, etc.) which are 
TABLE 1: Chemical composition of different grades of manganese ores.

\begin{tabular}{lcccccccc}
\hline Ore description & $\mathrm{T} \mathrm{Fe}$ & $\mathrm{T} \mathrm{Mn}$ & $\mathrm{SiO}_{2}$ & $\mathrm{Al}_{2} \mathrm{O}_{3}$ & $\mathrm{CaO}$ & $\mathrm{MgO}$ & $\mathrm{P}$ & $\mathrm{LOI}$ \\
\hline High Fe-low $\mathrm{Si}$ & 23.48 & 34.73 & 6.75 & 0.56 & 0.38 & 0.16 & 0.051 \\
Low Fe-low $\mathrm{Si}$ & 3.9 & 47.8 & 7.93 & 4.35 & 0.26 & 0.18 & 0.063 \\
Low Fe-high $\mathrm{Si}$ & 2.72 & 36.66 & 27.26 & 2.49 & 1.97 & 0.26 & 0.062 \\
High Fe-high Si & 33.24 & 13.67 & 16.32 & 1.32 & 0.2 & 0.06 & 0.12 & 10.88 \\
\hline
\end{tabular}

normally present in the form of complex minerals (e.g., Pyrolusite, bixbyite, braunite, manganite, hausmannite, tephroite, and rhodonite) [9]. Manganese ores can be classified according to their contents of manganese into different categories. The ores containing at least 35\% manganese are defined as manganese ores while the ores having 10-35\% Mn are known as ferruginous manganese ores [9]. The ores containing 5$10 \%$ manganese are defined as manganiferous ores while the ores containing less than $5 \%$ manganese with the balance of iron are classified as iron ores. The manganese ores are often found contaminated with iron and silica which affect the reduction process, the energy consumption, and the operation stability. Intensive work has been carried out to identify the reduction kinetics of manganese ores and the influence of different impurities on the high temperature metallurgical properties. The influence of iron and silica on the metallurgical properties of four different grades of manganese ores is discussed [11]. The ores are classified as high-iron highsilica, low-iron low-silica, high-iron low-silica, and low-iron high-silica ores. It was reported that the high-iron low-silica one exhibited a good reducibility and narrow melting range which is required for FeMn alloy and manganese-rich slag production. The low iron-low silica manganese ores showed that the highest melting temperature makes it suitable for SiMn alloy production. The low iron-high silica manganese ores exhibited low melting temperatures; therefore, it could be used for manganese-rich slag production. The high ironhigh silica manganese ore showed good reducibility with low melting temperature which makes it suitable for the production of manganese-rich slag. The investigation carried out on the reduction of siliceous manganese ore by graphite indicated that the manganese oxide is firstly dissolved into the molten $\mathrm{MnO}-\mathrm{SiO}_{2}-\mathrm{Al}_{2} \mathrm{O}_{3}-\mathrm{CaO}-\mathrm{MgO}$ slag, and then it is reduced from the slag $[12,13]$. The reduction of manganese oxide in slag is strongly retarded by silica. The carbothermal reduction of manganese oxides was studied in presence of hydrogen, helium, and argon at different temperatures $[14,15]$. It was found that the carbothermal reduction of $\mathrm{MnO}$ at constant temperature was the fastest in hydrogen followed by helium and the slowest in argon. This magnitude effect of the surrounding atmospheres on the reduction rate was decreased as the temperature increased from $1275^{\circ} \mathrm{C}$ to $1400^{\circ} \mathrm{C}$. The manganese oxides were reduced to $\alpha-\mathrm{Mn}$ and $\mathrm{Mn}_{23} \mathrm{C}_{6}$ and $\mathrm{Mn}_{7} \mathrm{C}_{3}$ depending on the carbon to ore ratio. $\mathrm{A}$ reduction retardation was accompanied with the reduction of manganese ores which are contaminated with iron oxides [16, 17]. The reduction of $\mathrm{Fe}_{2} \mathrm{O}_{3}-\mathrm{MnO}_{2}-\mathrm{SiO}_{2}$ mixed oxides with $\mathrm{CO}$ gas is investigated [18]. It was found that the formation of hard reducible fayalite-manganoan $\left[(\mathrm{Fe}, \mathrm{Mn})_{2} \mathrm{SiO}_{4}\right]$ phase resulted in a retardation of the reduction process [15]. The utilization of composite briquettes consisting of manganese ore, coke fines, and organic binder improved the thermal stability, softening property, and reducibility of manganese ore in smelting arc furnace [19].

The previous survey indicates that, in order to maintain a stable operation of ferromanganese production with lowest energy consumption, it is important to keep the metallurgical properties of the applied manganese ores at the optimum conditions. Although many experimental studies were carried out to estimate the effect of different parameters on the smelting reduction of manganese ores, few studies tried to estimate the magnitude's effect of the individual and interaction parameters on the overall reduction process. The factorial design provides a novel approach to precisely estimate the effect of different parameters either individually or collectively on the process [20-23]. The current study aims to investigate the effect of total iron and silica on the metallurgical properties of manganese ores using factorial design approach. Regression models are derived based on the experimental results of different manganese ores grades which are contaminated with unequal proportions of iron and silica [11]. The magnitude effects of the individual and combinations parameters on the low-temperature reduction disintegration, reduction index, and softening-melting range are evaluated.

\section{Materials and Methods}

2.1. Source and Analysis of Manganese Ores. A $2^{2}$ factorial design is used to determine the main effect of total iron and silica and their interactions on the low-temperature reduction disintegration index (RDI), reduction index (RI), and softening-melting property (SMP) of different grades of manganese ores. The testing methods of the reduced manganese ores including RDI, RI, and SMP are reported by Zhang et al. elsewhere [11]. The RDI is classified into $\mathrm{RDI}_{+6.3}$ (the ratio of reduced manganese ores with size larger than $6.3 \mathrm{~mm}$ after tumbling test, \%), $\mathrm{RDI}_{+3.15}$ (the ratio of reduced manganese ores with size larger than $3.15 \mathrm{~mm}$ after tumbling test, \%), and $\mathrm{RDI}_{-0.5}$ (the ratio of reduced manganese ores with size smaller than $0.5 \mathrm{~mm}$ after tumbling test, \%). The reduction index (RI) is classified into RIT (reduction index of total Fe-Mn oxides), RIM (reduction index of only manganese oxide), and RIF (reduction index of only iron oxide). The softening-melting property (SMP) is classified into $T_{S 1}$ (start of softening), $T_{S 2}$ (end of softening), $T_{m 1}$ (start of melting), and $T_{m 2}$ (end of melting). The chemical composition of the manganese ores is given in Table 1 [11].

2.2. Statistical Design. By convention, the total iron in manganese ores is denoted by " $A$." The average of iron content in the low iron-manganese ores is equal to $3.31 \%$ and the 
TABLE 2: Effect of total iron $(A)$, silica $(B)$, and their interaction $(A B)$ on on $\mathrm{RDI}_{+6.3}$.

\begin{tabular}{lcccc}
\hline Source of variance & The average effect & $\begin{array}{c}\text { Sum of square } \\
(\mathrm{SS})\end{array}$ & $\begin{array}{c}\text { Mean square (MS) } \\
(\mathrm{MS}=\mathrm{SS} / \text { degree of freedom) }\end{array}$ & $\begin{array}{c}\text { Magnitude effect, } \\
F_{o}\left(\mathrm{MS}_{\text {Variance }} / \mathrm{MS}_{E}\right)\end{array}$ \\
\hline$A$ & -1.1518 & 2.653286 & 2.653286 & 9.096124 \\
$B$ & 5.4581 & 59.58171 & 59.58171 & 204.2609 \\
$A B$ & -9.64705 & 186.1311 & 186.1311 & 638.1037 \\
Error & & 1.166777 & 0.291694 & \\
\hline Total & & 249.5329 & & \\
\hline
\end{tabular}

TABLE 3: Effect of total iron $(A)$, silica $(B)$, and their interaction $(A B)$ on $\mathrm{RDI}_{+3.15}$.

\begin{tabular}{lcccc}
\hline Source of variance & The average effect & $\begin{array}{c}\text { Sum of square } \\
(\mathrm{SS})\end{array}$ & $\begin{array}{c}\text { Mean square (MS) } \\
(\mathrm{MS}=\mathrm{SS} / \text { degree of freedom) }\end{array}$ & $\begin{array}{c}\text { Magnitude effect, } \\
F_{o}\left(\mathrm{MS}_{\text {Variance }} / \mathrm{MS}_{E}\right)\end{array}$ \\
\hline$A$ & 1.765325 & 6.232745 & 6.232745 & 17.63527 \\
$B$ & 4.867275 & 47.38073 & 47.38073 & 134.0617 \\
$A B$ & -6.47918 & 83.95942 & 83.95942 & 237.5594 \\
Error & & 1.4137 & 0.353425 & \\
\hline Total & & & \\
\hline
\end{tabular}

average of iron content in the high iron-manganese ores is equal to $28.36 \%$. Similarly, the silica will be denoted by " $B$." The average of silica content in the low silicon-manganese ores is equal to $7.34 \%$ and the average of silica content in the high silica-manganese ores is equal to $21.79 \%$.

Based on this concept, the effect of a factor is donated by a capital Latin letter. Thus " $A$ " refers to the effect of total iron, " $B$ " refers to the effect of $\mathrm{SiO}_{2}$, and “ $A B$ ” refers to the interaction combination effect of total $\mathrm{Fe}$ and $\mathrm{SiO}_{2}$. The low and high level of " $A$ " and " $B$ " are denoted by "-" and “+," respectively. The four treatment combinations in the design are usually represented by lowercase letters, where the high level of any factor in the treatment combination is denoted by the corresponding lowercase letter and the low level of a factor in the treatment combination is denoted by the absence of the corresponding letter. Thus, " $a$ " represents the treatment combination of $\mathrm{Fe}$ " $A$ " at high level and $\mathrm{SiO}_{2}$ " $B$ " at low level, " $b$ " represents " $A$ " at low level and " $B$ " at high level, and " $a b$ " represents both factors $\mathrm{Fe}$ and $\mathrm{SiO}_{2}(A$ and $B)$ at the high levels, while "(1)" is used to denote both factors at low levels.

\section{Results and Discussions}

3.1. Mathematical Formulations. Mathematical formulations are driven to estimate the effect of $\mathrm{Fe}, \mathrm{SiO}_{2}$, and their interaction $\left(\mathrm{Fe}-\mathrm{SiO}_{2}\right)$ on the metallurgical properties of manganese ores. The effect of " $A$ " at low level of $B$ is $[a-(1)]$ and the effect of " $A$ " at high level of $B$ is $[a b-b]$. The main effect of " $A$ " is the average of its effect at low and high level of $B$ as given in

$$
A=\frac{1}{2}\{[a b-b]+[a-(1)]\}=\frac{1}{2}[a b+a-b-(1)] .
$$

The average effect of " $B$ " can be calculated from the effect of " $B$ " at low level of " $A$ " $([b-(1)])$ and at the high level of " $A$ " (i.e., $[a b-a])$ as given in

$$
B=\frac{1}{2}\{[a b-a]+[b-(1)]\}=\frac{1}{2}[a b+b-a-(1)] .
$$

The interaction effect " $A B$ " is defined as the average difference between the effect of " $A$ " at the high level of " $B$ " and the effect of " $A$ " at the low level of " $B$ " as given in

$$
A B=\frac{1}{2}\{[a b-b]-[a-(1)]\}=\frac{1}{2}[a b+(1)-a-b] .
$$

The sum of squares (SS) of $A, B$, and $A B$ can be calculated as given in (4)-(6), respectively. Consider

$$
\begin{aligned}
\mathrm{SS}_{A} & =\frac{[a b+a-b-(1)]^{2}}{4}, \\
\mathrm{SS}_{B} & =\frac{[a b+b-a-(1)]^{2}}{4}, \\
\mathrm{SS}_{A B} & =\frac{[a b+(1)-a-b]^{2}}{4} .
\end{aligned}
$$

The total sum of squares $\left(\mathrm{SS}_{T}\right)$ and sum of squares $\left(\mathrm{SS}_{E}\right)$ can be calculated using (7) and (8) respectively. Consider

$$
\begin{gathered}
\mathrm{SS}_{T}=\sum_{i=1}^{2} \sum_{j=1}^{2} \sum_{k=1}^{n} y_{i j k}^{2}-\frac{y^{2}}{4}, \\
\mathrm{SS}_{E}=\mathrm{SS}_{T}-\mathrm{SS}_{A}-\mathrm{SS}_{B}-\mathrm{SS}_{A B} .
\end{gathered}
$$

\subsection{Application of Factorial Design}

3.2.1. Reduction Disintegration Index (RDI). The complete analyses of the effect of $\mathrm{Fe}(A)$ and/or $\mathrm{SiO}_{2}(B)$ on reduction disintegration index (RDI) of manganese ores can be calculated using (1)-(8). The effects of $\mathrm{Fe}$ and/or $\mathrm{SiO}_{2}$ on $\mathrm{RDI}_{+6.3}$, $\mathrm{RDI}_{+3.15}$, and $\mathrm{RDI}_{-0.5}$ are given in Tables $2-4$, respectively.

In Table 2, it can be seen that the highest negative effect on $\mathrm{RDI}_{+6.3}$ is exhibited by the interaction of iron and silica followed by the individual effect of iron. On the other hand, silica exhibited a positive effect on $\mathrm{RDI}_{+6.3}$ of the reduced manganese ores. The results in Table 3 indicate that both of 
TABLE 4: Effect of total iron $(A)$, silica $(B)$, and their interaction $(A B)$ on $\mathrm{RDI}_{-0.5}$.

\begin{tabular}{lcccc}
\hline Source of variance & The average effect & $\begin{array}{c}\text { Sum of square } \\
(\mathrm{SS})\end{array}$ & $\begin{array}{c}\text { Mean square (MS) } \\
(\mathrm{MS}=\mathrm{SS} / \text { degree of freedom) })\end{array}$ & $\begin{array}{c}\text { Magnitude effect, } \\
F_{o}\left(\mathrm{MS}_{\text {Variance }} / \mathrm{MS}_{E}\right)\end{array}$ \\
\hline$A$ & 0.185425 & 0.068765 & 0.068765 & 37.04831 \\
$B$ & 0.893125 & 1.595345 & 1.595345 & 859.5207 \\
$A B$ & 2.370475 & 11.2383 & 11.2383 & 6054.839 \\
Error & & 0.007424 & 0.001856 & \\
\hline Total & & 12.90984 & & \\
\hline
\end{tabular}

TABLE 5: Regression coefficient values for $\mathrm{RDI}_{+6.3}, \mathrm{RDI}_{+3.15}$, and $\mathrm{RDI}_{-0.5}$.

\begin{tabular}{lccccc}
\hline$Y$ & $\beta_{0}$ & $\beta_{1}$ & $\beta_{2}$ & $\beta_{12}$ & $\varepsilon$ \\
\hline $\mathrm{RDI}_{+6.3}$ & 76.18 & -0.5759 & 2.729 & -4.82353 & \pm 0.419 \\
$\mathrm{RDI}_{+3.15}$ & 83.96099 & 0.882662 & 2.433638 & -3.23959 & \pm 0.441 \\
$\mathrm{RDI}_{-0.5}$ & 5.95688 & 0.092713 & 0.446563 & 1.185238 & \pm 0.0386 \\
\hline
\end{tabular}

iron and silica have an individual positive effect on $\mathrm{RDI}_{+3.15}$ while the interaction coefficient of iron and silica affects negatively the $\mathrm{RDI}_{+3.15}$ of the reduced manganese ores. Table 4 indicates that the individual and collective parameters have positive effects on $\mathrm{RDI}_{-0.5}$ with relatively higher magnitude for the interaction coefficient parameter of iron with silica.

The experimental results can be generally expressed in terms of regression model as given in (9) for $\mathrm{RDI}_{+6.3}$, $\mathrm{RDI}_{+3.15}$, and $\mathrm{RDI}_{-0.5}$, respectively. Consider

$$
Y=\beta_{0}+\beta_{1} x_{1}+\beta_{2} x_{2}+\beta_{12} x_{1} x_{2}+\varepsilon,
$$

where $Y$ refers to $\mathrm{RDI}_{+6.3}, \mathrm{RDI}_{3.15}$, or $\mathrm{RDI}_{-0.5}, x_{1}$ is a coded variable representing the total iron, $x_{2}$ is a coded variable representing the $\mathrm{SiO}_{2}, \beta_{s}^{\prime}$ is regression coefficient, and $\varepsilon$ is the residual (the difference between observed and fitted point of the design). $\beta_{0}$ is the intercept which is the grand average of all observations; the regression coefficients $\beta_{1} \beta_{2}$ and $\beta_{12}$ are one-half the corresponding factor while $\varepsilon$ is the residual. The values of $\beta_{0}, \beta_{1}, \beta_{2}$, and $\varepsilon$ are given in Table 5 . In all cases, the residuals are very small and can be neglected.

The relation between the natural variables and the coded variable is given as follow: the coded variable is equal to [(natural variable $-1 / 2$ (variable at high level + variable at low level))/1/2(variable at high level - variable at low level)]. Consequently, the $\mathrm{RDI}_{+6.3}, \mathrm{RDI}_{+3.15}$, and $\mathrm{RDI}_{-0.5}$ can be predicted as a function of total iron and $\mathrm{SiO}_{2}$ as given in (10)(12), respectively. Consider

$$
\begin{aligned}
\mathrm{RDI}_{+6.3}= & 59.11397-0.0533[\text { TotalFe }] \\
& +0.730374\left[\mathrm{SiO}_{2}\right]+1.221772[\text { TotalFe }]\left[\mathrm{SiO}_{2}\right]
\end{aligned}
$$

$$
\begin{aligned}
\mathrm{RDI}_{+3.15}= & 69.68242-0.0358[\text { TotalFe }] \\
& +0.591889\left[\mathrm{SiO}_{2}\right]+0.903718[\text { TotalFe }]\left[\mathrm{SiO}_{2}\right],
\end{aligned}
$$

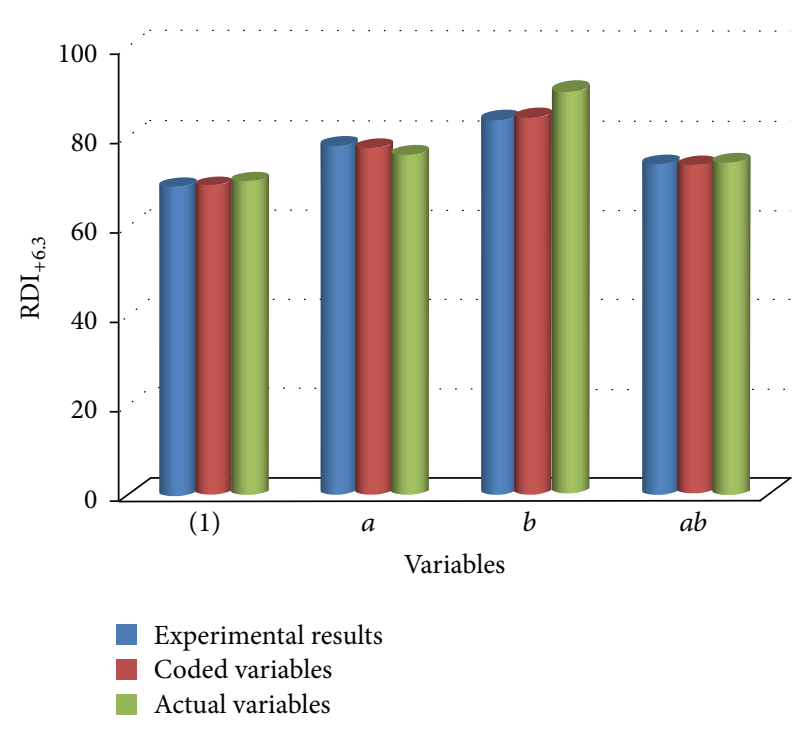

FIGURE 1: The experimental and predicted $\mathrm{RDI}_{+6.3}$ by using coded and actual variables.

$$
\begin{aligned}
\mathrm{RDI}_{-0.5}= & 7.960216-0.013098[\text { TotalFe }] \\
& -0.18336\left[\mathrm{SiO}_{2}\right]-0.14559[\text { TotalFe }]\left[\mathrm{SiO}_{2}\right] .
\end{aligned}
$$

The $\mathrm{RDI}_{+6.3}, \mathrm{RDI}_{+3.15}$, and $\mathrm{RDI}_{-0.5}$ for the different grades of manganese ores (low-Fe low-Si, high-Fe low-Si, low-Fe high-Si, and high-Fe high-Si manganese ores) are calculated based on (10)-(12). The calculated values of RDI are compared to the experimental results as can be seen in Figures 1,2, and 3. The given notations summarized the grade of ores as follows: refers to low-Fe low-Si ore; $a$ refers to high-Fe low-Si ore; $b$ refers to low-Fe high-Si ore; $a b$ refers to high-Fe high-Si ore. It can be seen that, in all cases, the coded and actual variables are in good agreement with those of the experimental results. The $\mathrm{RDI}_{+6.3}$ and $\mathrm{RDI}_{+3.15}$ are the highest in low-Fe high-Si ores and the lowest in low-Fe low$\mathrm{Si}$ ores. This indicates that silica has the ability to improve the strength of manganese ore during the reduction at $500^{\circ} \mathrm{C}$ [11]. In the iron-manganese oxides, manganese ferrite $\left(\mathrm{Fe}_{2} \mathrm{MnO}_{4}\right)$ is formed in vicinity of large pores as a result of solid solution reaction between $\mathrm{MnO}$ and $\mathrm{Fe}_{2} \mathrm{O}_{3}$. On the other hand, the presence of silica in iron-manganese ore is able to diminish the formation of manganese ferrite $\left(\mathrm{MnFe}_{2} \mathrm{O}_{4}\right)$, consequently decreasing the porosity and improving the strength of the ore $[18,24]$. The iron content has a significant effect on 
TABLE 6: Effect of total iron $(A)$, silica $(B)$, and their interaction $(A B)$ on the RIT.

\begin{tabular}{lcccc}
\hline Source of variance & The average effect & $\begin{array}{c}\text { Sum of square } \\
(\mathrm{SS})\end{array}$ & $\begin{array}{c}\text { Mean square (MS) } \\
(\mathrm{MS}=\mathrm{SS} / \text { degree of freedom) }\end{array}$ & $\begin{array}{c}\text { Magnitude effect, } \\
F_{o}\left(\mathrm{MS}_{\text {Variance }} / \mathrm{MS}_{E}\right)\end{array}$ \\
\hline$A$ & 19.687 & 775.1559 & 775.1559 & 3994.748 \\
$B$ & 6.3685 & 81.11558 & 81.11558 & 418.0273 \\
$A B$ & 6.268 & 78.57565 & 78.57565 & 404.9378 \\
Error & & 0.776175 & 0.194044 & \\
\hline Total & & 935.6233 & \\
\hline
\end{tabular}

TABLE 7: Effect of total iron $(A)$, silica $(B)$, and their interaction $(A B)$ on the RIM.

\begin{tabular}{lcccc}
\hline Source of variance & The average effect & $\begin{array}{c}\text { Sum of square } \\
(\mathrm{SS})\end{array}$ & $\begin{array}{c}\text { Mean square (MS) } \\
(\mathrm{MS}=\mathrm{SS} / \text { degree of freedom) }\end{array}$ & $\begin{array}{c}\text { Magnitude effect, } \\
F_{o}\left(\mathrm{MS}_{\text {Variance }} / \mathrm{MS}_{E}\right)\end{array}$ \\
\hline$A$ & -2.3 & 10.58 & 10.58 & 2116 \\
$B$ & -0.3 & 0.18 & 0.18 & 36 \\
$A B$ & -1.4 & 3.92 & 3.92 & 784 \\
Error & & 0.02 & 0.005 & \\
\hline Total & & 14.7 & & \\
\hline
\end{tabular}

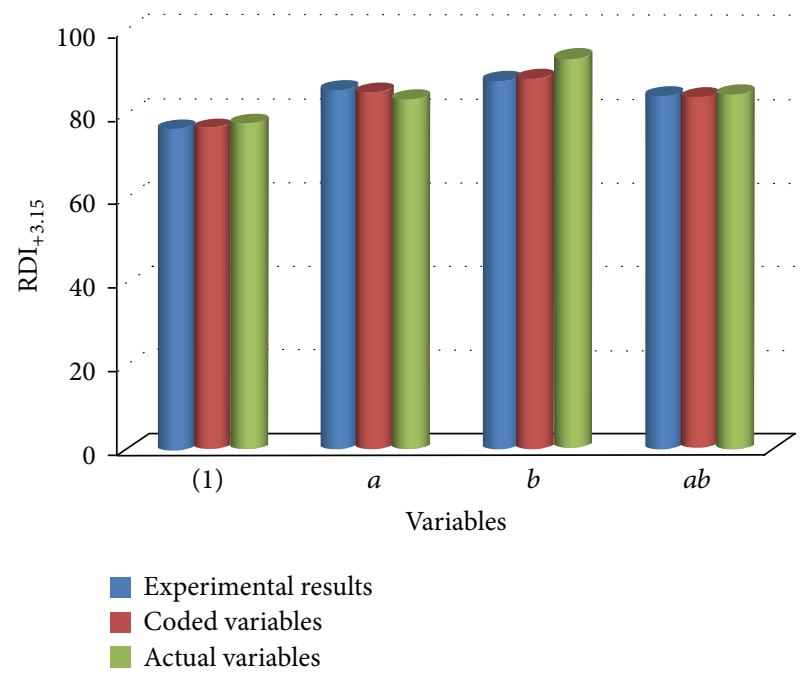

FIGURE 2: The experimental and predicted $\mathrm{RDI}_{+3.15}$ by using coded and actual variables.

the reduction disintegration index. The ore disintegration increases with iron due to the crystal distortion which is accompanied by the transformation of hematite to magnetite. Such disintegration is caused on one hand by lattice transformations and on the other hand by an anisotropic reaction rate [25]. Hematite crystallizes in hexagonal rhombohedral lattice while magnetite has an inverse spinel lattice structure. During the transformation from hematite to magnetite, a layer of close magnetite grows on the surface of the porous hematite and results in cracks and disintegrations. The unit cell volume of magnetite is equal to $592.07 \AA^{3}$ which it is equal to $302.72 \AA^{3}$ for hematite. This results in a disintegration of the ore during reduction. In addition, the transformation of $\mathrm{MnO}_{2}$ into $\mathrm{Mn}_{2} \mathrm{O}_{3}$ is accompanied by sharp increase in the cell volume from 55.64 to 834.56 [11]. Therefore, the index of reduction disintegration is decreased as the iron and/or manganese content in the ore increased.

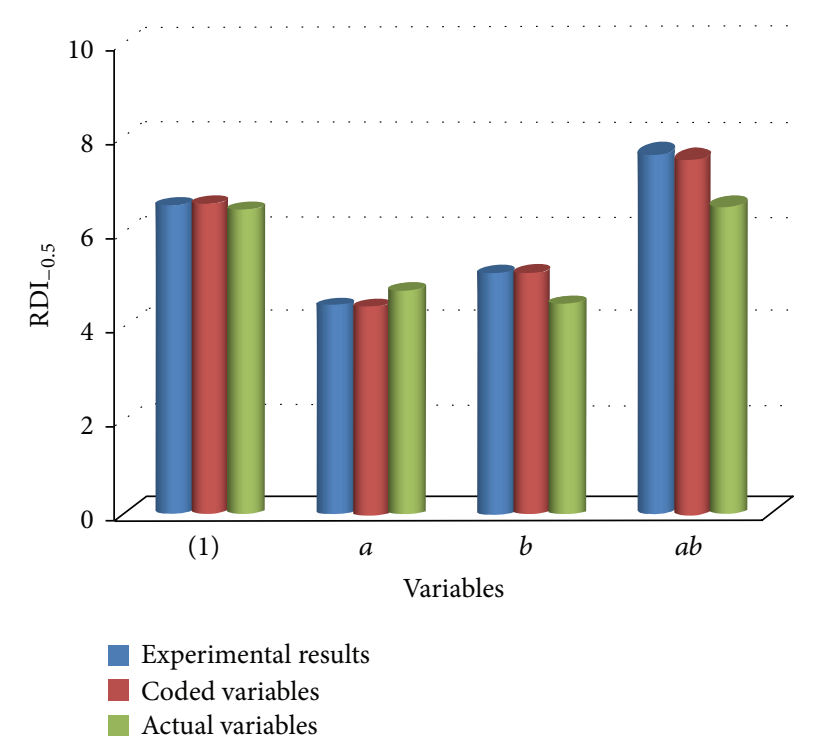

FIGURE 3: The experimental and predicted $\mathrm{RDI}_{-0.5}$ by using coded and actual variables.

3.2.2. Reduction Index (RI). The effect of total Fe and/or silica on the reduction index is calculated based on the total Fe-Mn oxides (RIT), Mn oxide (RIM), and Fe oxide (RIF) as given in Tables 6-8. Table 6 indicates that total Fe has the highest positive effect on the total reduction RIT. Both of the silica and the interaction of total Fe with silica have almost equal positive effect which is lower than the individual effect of $\mathrm{Fe}$. Table 7 shows that all parameters have negative effect on the reduction of manganese (RIM) with relatively higher negative effect of total Fe. Table 8 indicates that the total iron has a relatively high positive effect on the reduction of iron oxide (RIF). On the other hand, the interaction coefficient between Fe and silica exhibited a negative effect on the reduction of iron oxides.

The results of experiments can be expressed in terms of regression models of RIT, RIM, and RIF as given in (13). The 
TABLE 8: Effect of total iron $(A)$, silica $(B)$, and their interaction $(A B)$ on the RIF.

\begin{tabular}{lcccc}
\hline Source of variance & The average effect & $\begin{array}{c}\text { Sum of square } \\
(\mathrm{SS})\end{array}$ & $\begin{array}{c}\text { Mean square (MS) } \\
(\mathrm{MS}=\mathrm{SS} / \text { degree of freedom) }\end{array}$ & $\begin{array}{c}\text { Magnitude effect, } \\
F_{o}\left(\mathrm{MS}_{\text {Variance }} / \mathrm{MS}_{E}\right)\end{array}$ \\
\hline$A$ & 21.4555 & 920.677 & 920.677 & 2537.032 \\
$B$ & 0.613 & 0.751538 & 0.751538 & 2.07095 \\
$A B$ & -2.603 & 13.55122 & 13.55122 & 37.34195 \\
Error & & 1.451581 & 0.362895 & \\
\hline Total & & 936.4313 & & \\
\hline
\end{tabular}

TABLE 9: Regression coefficient values for RIT, RIM, and RIF.

\begin{tabular}{lccccc}
\hline$Z$ & $\beta_{0}$ & $\beta_{1}$ & $\beta_{2}$ & $\beta_{12}$ & $\varepsilon$ \\
\hline RIT & 61.24925 & 9.8435 & 3.18425 & 3.134 & \pm 0.389 \\
RIM & 98.15 & -1.15 & -0.15 & -0.7 & \pm 0.05 \\
RIF & 84.39425 & 10.7277 & 0.3065 & -1.3015 & \pm 0.483 \\
\hline
\end{tabular}

values of $\beta_{0}, \beta_{1}, \beta_{2}$, and $\varepsilon$ are given in Table 9. In all cases, the residuals are very small and can be neglected. Consider

$$
Z=\beta_{0}+\beta_{1} x_{1}+\beta_{2} x_{2}+\beta_{12} x_{1} x_{2}+\varepsilon,
$$

where $Z$ refers to RIT, RIM, or RIF.

The RIT, RIM, RIF can be predicted as a function of total iron and $\mathrm{SiO}_{2}$ as given in (14)-(16), respectively. The calculated values of RIT, RIM, and RIF are compared to the experimetal results as can be seen in Figures 4-6. It can be seen that, in all cases, the coded and actual variables are in a good agreement with the experimental data. Consider

$$
\begin{aligned}
\mathrm{RI}= & 50.37273+0.034632[\text { TotalFe }] \\
& +0.281486\left[\mathrm{SiO}_{2}\right]-0.10768[\text { TotalFe }]\left[\mathrm{SiO}_{2}\right], \\
\mathrm{RIM}= & 98.12223-0.00774[\text { TotalFe }] \\
& +0.02085\left[\mathrm{SiO}_{2}\right]+0.101729[\text { TotalFe }]\left[\mathrm{SiO}_{2}\right] \\
\mathrm{RIF}= & 66.89649-0.01438[\text { TotalFe }] \\
& +1.065985\left[\mathrm{SiO}_{2}\right]+0.270166[\text { TotalFe }]\left[\mathrm{SiO}_{2}\right] .
\end{aligned}
$$

It can be seen in Figure 4 that high-Fe high-Si and highFe low-Si manganese ores exhibited the highest reduction index. On the other hand, the lowest reduction index was exhibited in low-Fe low-Si and low-Fe high-Si ones. This indicates that the reduction index of manganese ore increases as iron oxide content increases. The reduction index based on manganese oxide (RIM) is almost identical for the different grades of manganese ores as shown in Figure 5. This can be attributed to the simple reduction of $\mathrm{MnO}_{2}$ to $\mathrm{MnO}$. The reduction index based on iron oxide (RIF) is high in the ores rich with iron and low in the ore poor in iron oxides as shown in Figure 6. This is attributed to the higher reducibility of iron oxides compared to that of manganese oxides. Although the reduction of wüstite $\left(\mathrm{Fe}_{x} \mathrm{O}\right)$ to metallic iron required relatively high potential of reducing gas $\left(\eta_{\mathrm{CO}} \approx\right.$ $30 \%, \eta_{\mathrm{H} 2} \approx 30 \%$ ), the reduction of $\mathrm{MnO}$ to $\mathrm{Mn}$ metal is more

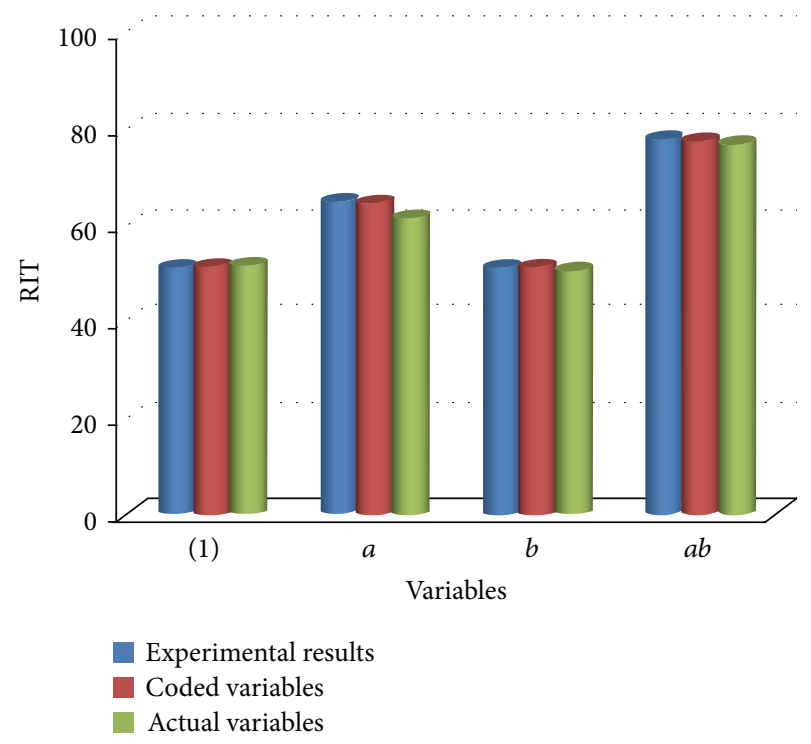

FIGURE 4: The experimental and predicted RIT by using coded and actual variables.

complicated and can be only proceeded by solid carbon at very high temperature $\left(\approx 1423^{\circ} \mathrm{C}\right)$. Therefore, the reduction index decreased as manganese content increased.

3.2.3. Softening-Melting Property (SMP). A mathematical regression model is derived to estimate the effect of total iron and/or silica on the softening-melting property of manganese ores during reduction. The softening ranges can be estimated based on the determination of temperature at which the reduced ores start to soften $\left(T_{S 1}\right.$ : starting of softening) and the temperature at which the softening finsihed $\left(T_{S 2}\right.$ : end of softening). The melting range can be determined based on the identification of the start of melting $\left(T_{m 1}\right)$ and the end of melting $\left(T_{m 2}\right)$. The effects of total iron and/or silica on the softening property of reduced manganese ores are given in Tables 10 and 11, respectively. It can be seen that the iron and silica affect negatively the start and the end softening temperature.

The effect of iron and/or silica content on the melting property of manganese ores including $T_{m 1}$ and $T_{m 2}$ is given in Tables 12 and 13, respectively. As can be seen in Table 12, the iron and the iron with silica affect positively the start temperature of melting while silica exhibited a negative effect on the start temperature of melting. Both of iron and silica decreased the end temperature of melting of manganese ore, 
TABLE 10: Effect of total iron $(A)$, silica $(B)$, and their interaction $(A B)$ on $T_{S 1}$.

\begin{tabular}{lcccc}
\hline Source of variance & The average effect & $\begin{array}{c}\text { Sum of square } \\
(\mathrm{SS})\end{array}$ & $\begin{array}{c}\text { Mean square (MS) } \\
(\mathrm{MS}=\mathrm{SS} / \text { degree of freedom) }\end{array}$ & $\begin{array}{c}\text { Magnitude effect, } \\
F_{o}\left(\mathrm{MS}_{\text {Variance }} / \mathrm{MS}_{E}\right)\end{array}$ \\
\hline$A$ & -29.5 & 1740.5 & 1740.5 & 386.7778 \\
$B$ & -47.5 & 4512.5 & 4512.5 & 1002.778 \\
$A B$ & -42.5 & 3612.5 & 3612.5 & 802.7778 \\
Error & & 18 & 4.5 & \\
\hline Total & & 9883.5 & & \\
\hline
\end{tabular}

TABLE 11: Effect of total iron $(A)$, silica $(B)$, and their interaction $(A B)$ on $T_{S 2}$.

\begin{tabular}{lcccc}
\hline Source of variance & The average effect & $\begin{array}{c}\text { Sum of square } \\
(\mathrm{SS})\end{array}$ & $\begin{array}{c}\text { Mean square (MS) } \\
(\mathrm{MS}=\mathrm{SS} / \text { degree of freedom) }\end{array}$ & $\begin{array}{c}\text { Magnitude effect, } \\
F_{o}\left(\mathrm{MS}_{\text {Variance }} / \mathrm{MS}_{E}\right)\end{array}$ \\
\hline$A$ & -8 & 128 & 128 & 10.24 \\
$B$ & -64 & 8192 & 8192 & 655.36 \\
$A B$ & -10 & 200 & 200 & 16 \\
Error & & 50 & 12.5 & \\
\hline Total & & 8570 & & \\
\hline
\end{tabular}

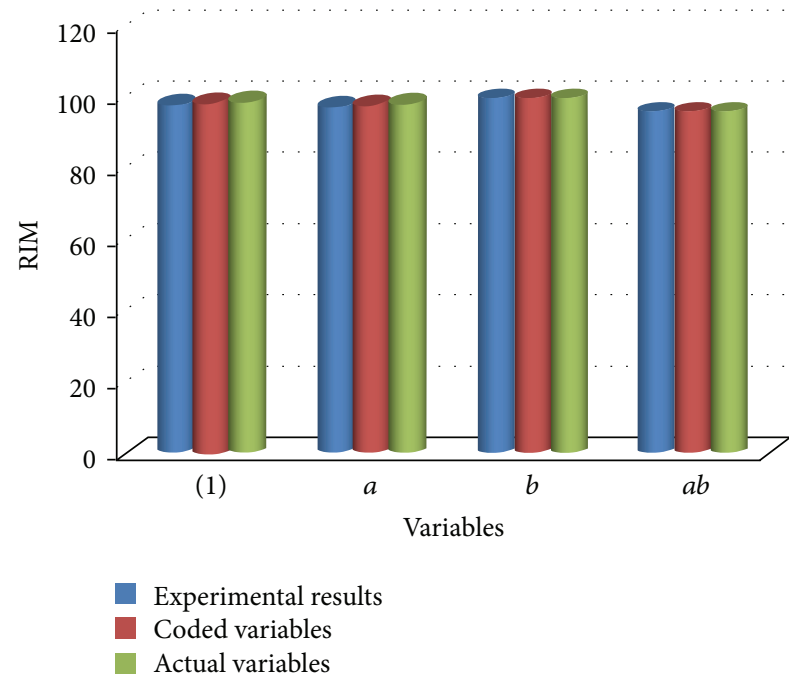

FIGURE 5: The experimental and predicted RIM by using coded and actual variables.

while the interaction of iron and silica has positive effect on the end of melting as given in Table 13.

The relation between the natural variables and the coded variable for $T_{S 1}, T_{S 2}, T_{m 1}$, and $T_{m 2}$ can be summarized in (17). The values of $\beta_{0}, \beta_{1}, \beta_{2}$, and $\varepsilon$ are given in Table 14. Consider

$$
H=\beta_{0}+\beta_{1} x_{1}+\beta_{2} x_{2}+\beta_{12} x_{1} x_{2}+\varepsilon,
$$

where $H$ refers to $T_{S 1}, T_{S 2}, T_{m 1}$, or $T_{m 2}$.

The $T_{S 1}, T_{S 2}, T_{m 1}$, and $T_{m 2}$ can be predicted as a function of total iron and $\mathrm{SiO}_{2}$ as given in (18)-(21), respectively. The calculated values of $T_{S 1}, T_{S 2}, T_{m 1}$, and $T_{m 2}$ are compared to the experimental results as can be seen in Figures 7-10. It can be seen that, in all cases, the coded and actual variables are in a good agreement with the experimental results. Consider

$$
\begin{aligned}
T_{S 1}= & 1135.617-0.23482[\text { TotalFe }] \\
& +2.242574\left[\mathrm{SiO}_{2}\right]+0.431248[\text { TotalFe }]\left[\mathrm{SiO}_{2}\right],
\end{aligned}
$$

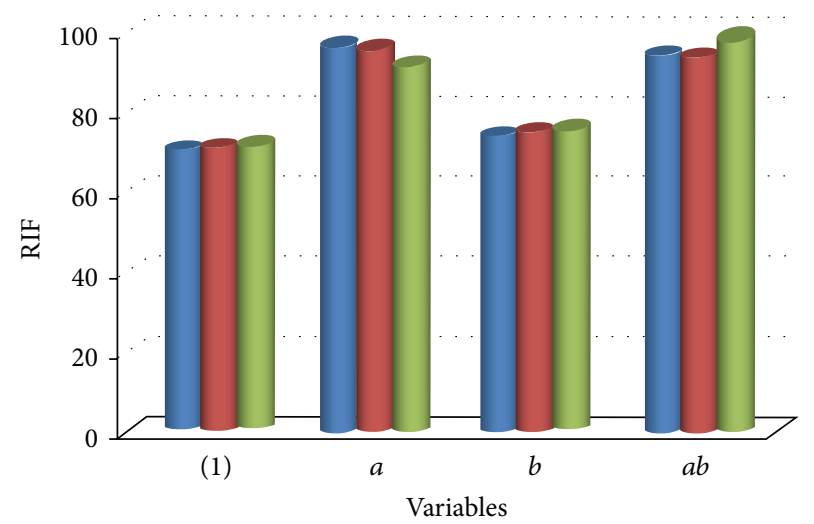

Experimental results

Coded variables

Actual variables

FIGURE 6: The experimental and predicted RIF by using coded and actual variables.

$$
\begin{aligned}
T_{S 2}= & 1297.323-0.05525[\text { TotalFe }] \\
& +0.485396\left[\mathrm{SiO}_{2}\right]-3.55414[\text { TotalFe }]\left[\mathrm{SiO}_{2}\right], \\
T_{m 1}= & 1309.35+0.121556[\text { TotalFe }] \\
& -0.01398\left[\mathrm{SiO}_{2}\right]-7.39197[\text { TotalFe }]\left[\mathrm{SiO}_{2}\right], \\
T_{m 2}= & 1399.393+0.165758[\text { TotalFe }] \\
& -3.17275\left[\mathrm{SiO}_{2}\right]-8.29953[\text { TotalFe }]\left[\mathrm{SiO}_{2}\right] .
\end{aligned}
$$

Figures 7 and 10 showed that the lowest start temperature of softening $\left(T_{S 1}\right)$ and melting $\left(T_{m 1}\right)$ is exhibited in high-Fe high-Si manganese ore which is equal to $1062-1089^{\circ} \mathrm{C}$ and $1199.5-1225^{\circ} \mathrm{C}$, respectively. Figures 8 and 11 clarify that the highest end of softening $\left(T_{S 2}\right)$ and melting $\left(T_{m 2}\right)$ is exhibited in high-Fe low-Si manganese ore which is equal to $1152-$ $1154^{\circ} \mathrm{C}$ and $1273-1276^{\circ} \mathrm{C}$, respectively. This indicates that the 
TABLE 12: Effect of total iron $(A)$, silica $(B)$, and their interaction $(A B)$ on $T_{m 1}$.

\begin{tabular}{lcccc}
\hline Source of variance & The average effect & $\begin{array}{c}\text { Sum of square } \\
(\mathrm{SS})\end{array}$ & $\begin{array}{c}\text { Mean square (MS) } \\
(\mathrm{MS}=\mathrm{SS} / \text { degree of freedom })\end{array}$ & $\begin{array}{c}\text { Magnitude effect, } \\
F_{o}\left(\mathrm{MS}_{\text {Variance }} / \mathrm{MS}_{E}\right)\end{array}$ \\
\hline$A$ & 44 & 3872 & 3872 & 1936 \\
$B$ & -79 & 12482 & 12482 & 6241 \\
$A B$ & 22 & 968 & 968 & 484 \\
Error & & 8 & 2 & \\
\hline Total & & 17330 & & \\
\hline
\end{tabular}

TABLE 13: Effect of total iron $(A)$, silica $(B)$, and their interaction $(A B)$ on $T_{m 2}$.

\begin{tabular}{lcccc}
\hline Source of variance & The average effect & $\begin{array}{c}\text { Sum of square } \\
(\mathrm{SS})\end{array}$ & $\begin{array}{c}\text { Mean square (MS) } \\
(\mathrm{MS}=\mathrm{SS} / \text { degree of freedom) }\end{array}$ & $\begin{array}{c}\text { Magnitude effect, } \\
F_{o}\left(\mathrm{MS}_{\text {Variance }} / \mathrm{MS}_{E}\right)\end{array}$ \\
\hline$A$ & -19 & 722 & 722 & 361 \\
$B$ & -82 & 13448 & 13448 & 6724 \\
$A B$ & 30 & 1800 & 1800 & 900 \\
Error & & 8 & 2 & \\
\hline Total & & 15978 & & \\
\hline
\end{tabular}

TABLE 14: Values of regression coefficient for $T_{S 1}, T_{S 2}, T_{m 1}$, and $T_{m 2}$.

\begin{tabular}{lccccc}
\hline & $\beta_{0}$ & $\beta_{1}$ & $\beta_{2}$ & $\beta_{12}$ & $\varepsilon$ \\
\hline$T_{S 1}$ & 1123.25 & -14.75 & -23.75 & -21.25 & \pm 1.5 \\
$T_{S 2}$ & 1240.5 & -4.0 & -32.0 & -5.0 & \pm 2.5 \\
$\Delta T_{S}$ & 119.6888 & 11.65125 & -8.33125 & 16.29125 & \pm 0.7 \\
$T_{m 1}$ & 1229.5 & 22.0 & -39.5 & 11.0 & \pm 1.0 \\
$T_{m 2}$ & 1266.5 & -9.5 & -41.0 & 15.0 & \pm 1.0 \\
$\Delta T_{m}$ & 36.66 & -32.1825 & -2.0175 & 3.51 & \pm 0.37 \\
\hline
\end{tabular}

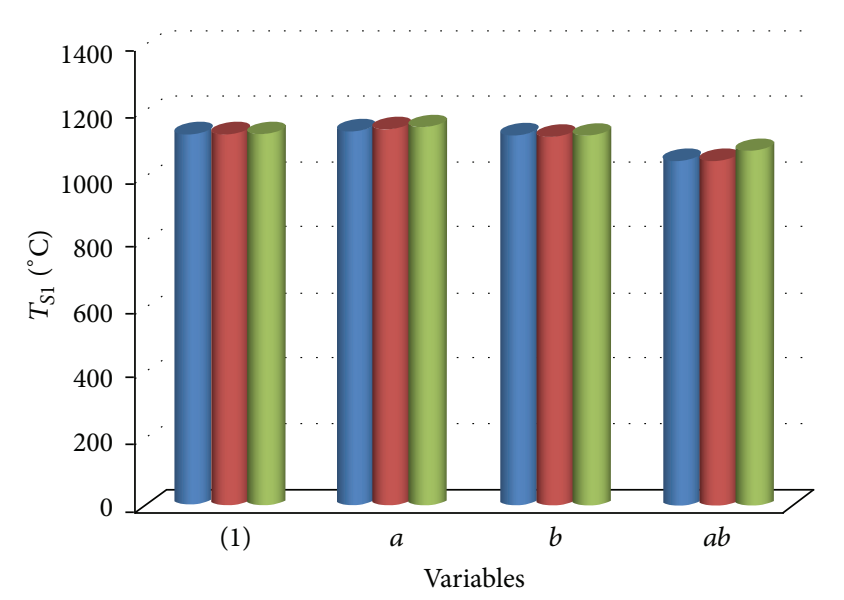

Experimental results

Coded variables

Actual variables

Figure 7: The experimental and predicted $T_{S 1}$ by using coded and actual variables.

presence of relatively high percentage of silica resulted in a decrease of the start softening and melting temperatures. This can be attributed to the formation of relatively low melting rhodonite phase $\left(\mathrm{MnSiO}_{3}\right.$; m.p. $\left.1242^{\circ} \mathrm{C}\right)$ as a result of the reaction between $\mathrm{SiO}_{2}$ and $\mathrm{MnO}$ [26]. The formation of low melting rhodonite phase resulted in a narrow softening range $\left(T_{\Delta S}\right)$ in low-Fe high- $\mathrm{SiO}_{2}$ manganese ore as can be seen in

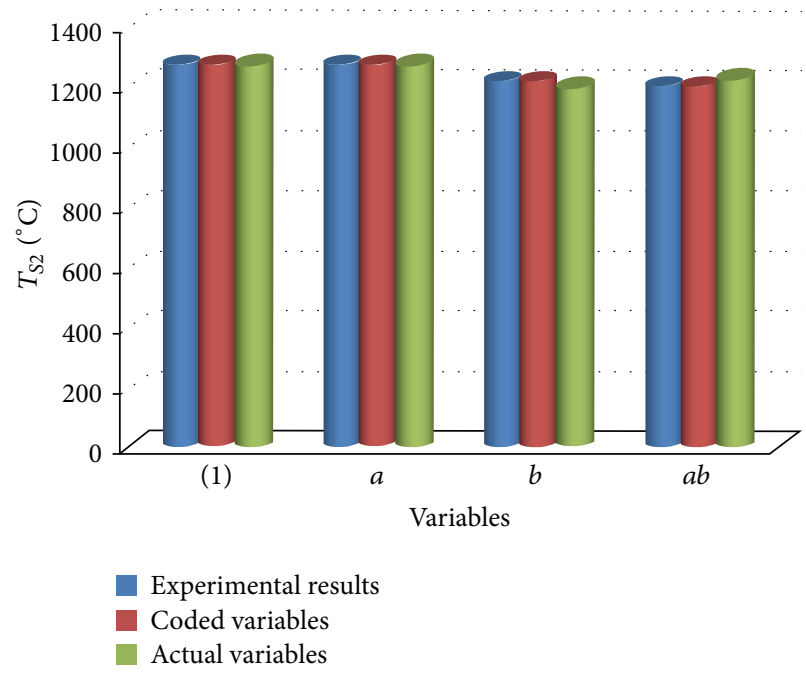

FIGURE 8: The experimental and predicted $T_{S 2}$ by using coded and actual variables.

Figure 9. The high-Fe low-si and high-Fe high-si manganese ores showed a narrow melting range as can be seen in Figure 12. This can be attributed to the formation Fe-Mn olivine in the presence of relatively high concentration of iron [11].

Based on the previous findings, it can be concluded that the factorial design is very useful approach to predict and precisely estimate the effect of different impurities such as $\mathrm{Fe}$ and/or Si which commonly contaminate the manganese ores and affect negatively the smelting reduction process. The derived mathematical regression models are able to predict the reduction disintegration index, reduction index, and the softening-melting property of manganese ores as a function of the content of total iron and silica.

\section{Conclusions}

In the current study, a factorial design is built on the experimental data of four grades of manganese ores containing 


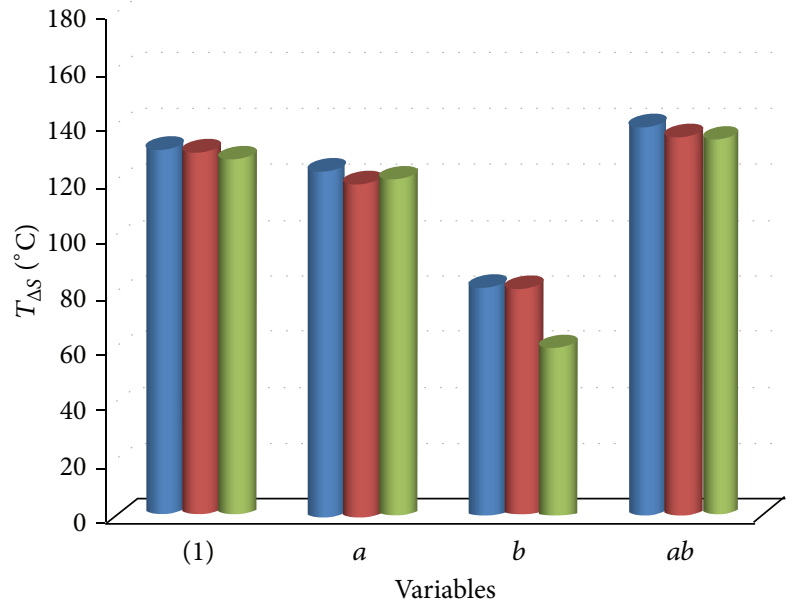

Experimental results

Coded variables

Actual variables

Figure 9: The softening range $\left(T_{\Delta S}\right)$ for experimental, coded, and actual variables.

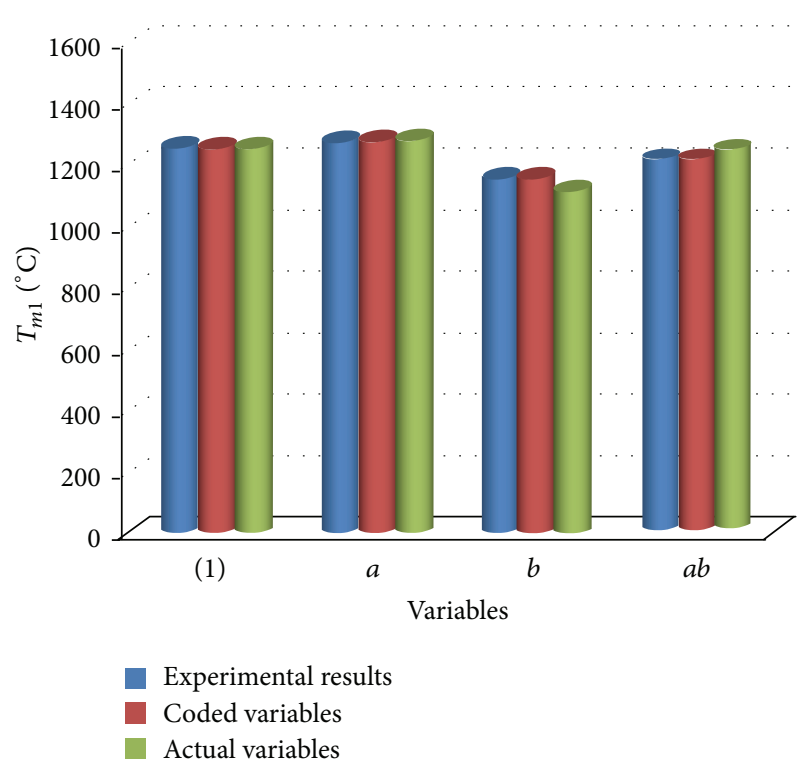

FIGURE 10: The experimental and predicted $T_{m 1}$ by using coded and actual variables.

different percentages of iron and silica (low-Fe high-Si, highFe low-Si, low-Fe high-Si, and high-Fe high-Si manganese ores). The main findings can be summarized as follow.

(1) Regression formulations are derived to estimate the effect of total $\mathrm{Fe}$ and/or $\mathrm{SiO}_{2}$ on the reduction disintegration indexes $\left(\mathrm{RDI}_{+6.3}, \mathrm{RDI}_{+3.15}\right.$, and $\left.\mathrm{RDI}_{-0.5}\right)$ of manganese ores. The $\mathrm{RDI}_{+6.3}$ and $\mathrm{RDI}_{+3.15}$ increased with the individual effect of $\mathrm{SiO}_{2}$ and the interaction effect of $\mathrm{Fe}-\mathrm{SiO}_{2}$ while they decreased as the total $\mathrm{Fe}$ increased. The $\mathrm{RDI}_{-0.5}$ increased with $\mathrm{Fe}$ and decreased with individual effect of silica and the interaction effect of $\mathrm{Fe}-\mathrm{SiO}_{2}$ in the manganese ores.

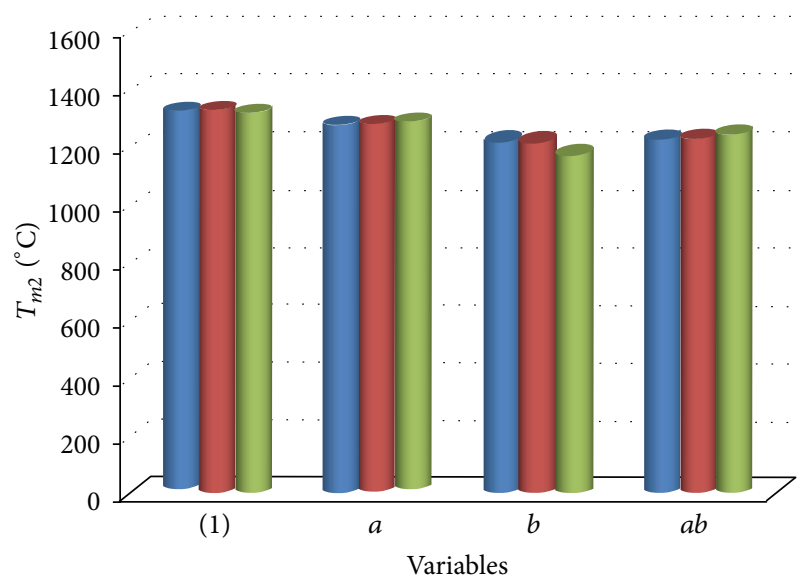

Experimental results

Coded variables

Actual variables

FIgURE 11: The experimental and predicted $T_{m 2}$ by using coded and actual variables.

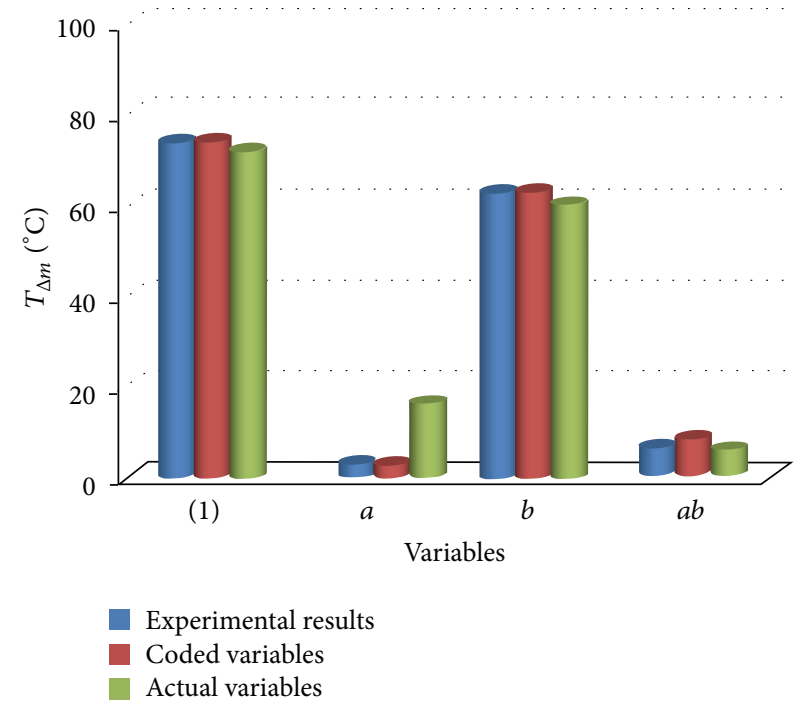

Figure 12: The melting range $\left(T_{\Delta m}\right)$ for experimental, coded, and actual variables.

(2) The effect of total Fe and/or $\mathrm{SiO}_{2}$ on the reduction indexes (total reduction of manganese and iron oxides (RIT), manganese oxides reduction (RIM), and iron oxides reduction (RIF)) is developed. The RIT and RIF increased as the iron oxide content in manganese ore increased. The RIM was almost identical due to the simple conversion of $\mathrm{MnO}_{2}$ to $\mathrm{MnO}$.

(3) The effect of total iron and $\mathrm{SiO}_{2}$ on the softeningmelting property (start of softening $\left(T_{S 1}\right)$ and end of softening $\left(T_{S 2}\right)$, start of melting $\left(T_{m 1}\right)$, and end of melting $\left(T_{m 2}\right)$ ) is mathematically derived. The developed formulations could be used to precisely predict the effect of total Fe and silica on the softeningmelting property of manganese ores. 
(4) The validation of regressions formulations was found to be in a good agreement with the experimental data which indicates the efficiency of the factorial design to predict the metallurgical properties of manganese ores under the influence of different impurities.

\section{Conflict of Interests}

The authors declare that there is no conflict of interests regarding the publication of this paper.

\section{References}

[1] S.-M. Jung, C.-H. Rhee, and D.-J. Min, "Thermodynamic properties of manganese oxide in BOF slags," ISIJ International, vol. 42, no. 1, pp. 63-70, 2002.

[2] A. Ahmed, S. N. Ghali, M. Eissa, and S. A. El Badry, "Influence of partial replacement of nickel by nitrogen on microstructure and mechanical properties of austenitic stainless steel," Journal of Metallurgy, vol. 2011, Article ID 639283, 6 pages, 2011.

[3] S. N. Ghali, "Low carbon high nitrogen low nickel stainless steel," Steel Research International, vol. 84, no. 5, pp. 450-456, 2013.

[4] S. N. Ghali, A. Ahmed, M. Eissa, H. El-Faramawy, M. Mishreky, and T. Mattar, "Production and application of advanced high nitrogen steel," in International Conference on Science and Technology of Ironmaking and Steelmaking, Jamshedpur, India, December 2013.

[5] E. T. Turkdogan, Fundamental of Steelmaking, The Institute of Materials, London, UK, 1996.

[6] B. K. Sedumedi and X. Pan, "Benchmarking techniques in ferromanganse production," in Proceedings of the International Conference on Mining, Mineral Processing and Metallurgical Engineering (ICMMME '13), pp. 158-163, Johannesburg, South Africa, April 2013.

[7] S.-M. Jung, S.-H. Kim, C.-H. Rhee, and D.-J. Min, "Thermodynamic study on $\mathrm{MnO}$ behavior in $\mathrm{MgO}$-saturated slag containing FeO," ISIJ International, vol. 33, no. 10, pp. 10491054, 1993.

[8] R. Sen, "Production of ferro manganese through blast furnace route," in Proceedings of the National Workshop on Ferro Alloy Industries in the Liberalised Economy, pp. 83-91, NML, Jamshedpur, India, 1997.

[9] R. Kononov, O. Ostrovski, and S. Ganguly, "Carbothermal solid state reduction of manganese ores: 1. Manganese ore characterisation," ISIJ International, vol. 49, no. 8, pp. 1099-1106, 2009.

[10] M. Eissa, H. El-Faramawy, A. Ahmed, S. Nabil, and H. Halfa, "Parameters affecting the production of high carbon ferromanganese in closed submerged arc furnace," Journal of Minerals and Materials Characterization and Engineering, vol. 11, no. 1, pp. 1-20, 2012.

[11] Y. Zhang, Y. Zhang, Z. You, Y. Zhao, G. Li, and T. Jiang, "Study on the metallurgical performance of typical manganese ores," in 5th International Symposium on High Temperature Metallurgical Processing, pp. 345-352, TMS, John Wiley \& Sons, San Diego, Calif, USA, 2014.

[12] O. I. Ostrovski and T. J. M. Webb, "Reduction of siliceous manganese ore by graphite," ISIJ International, vol. 35, no. 11, pp. 1331-1339, 1995.
[13] M. Yastreboff, O. Ostrovski, and S. Ganguly, "Carbothermic reduction of manganese from manganese ore and ferromanganese slag," in Proceedings of the 8th International Ferroalloys Congress, pp. 263-270, Beijing, China, June 1998.

[14] R. Kononov, O. Ostrovski, and S. Ganguly, "Carbothermal solid state reduction of manganese ores: 2. Non-isothermal and isothermal reduction in different gas atmospheres," ISIJ International, vol. 49, no. 8, pp. 1107-1114, 2009.

[15] R. Kononov, O. Ostrovski, and S. Ganguly, "Carbothermal solid state reduction of manganese ores: 3. Phase development," ISIJ International, vol. 49, no. 8, pp. 1115-1122, 2009.

[16] M. S. Fahim, H. El Faramawy, A. M. Ahmed, S. N. Ghali, and A. T. Kandil, "Characterization of Egyptian manganese ores for production of high carbon ferromanganese," Journal of Minerals and Materials Characterization and Engineering, vol. 1, no. 2, pp. 68-74, 2013.

[17] A. A. El-Geassy, M. I. Nasr, A. A. Omar, and E. A. Mousa, "Isothermal reduction behaviour of $\mathrm{MnO}_{2}$ doped $\mathrm{Fe}_{2} \mathrm{O}_{3}$ compacts with $\mathrm{H}_{2}$ at 1073-1373 K," Ironmaking and Steelmaking, vol. 35, no. 7, pp. 531-538, 2008.

[18] A.-H. A. El-Geassy, M. I. Nasr, A. A. Omar, and E.-S. A. Mousa, "Influence of $\mathrm{SiO}_{2}$ and/or $\mathrm{MnO}_{2}$ on the reduction behaviour and structure changes of $\mathrm{Fe}_{2} \mathrm{O}_{3}$ compacts with $\mathrm{CO}$ gas," ISIJ International, vol. 48, no. 10, pp. 1359-1367, 2008.

[19] Y. Huaming and Q. Guanzhou, "Fabrication and industrial application of ferromanganese composite briquette," Journal of Central South University of Technology, vol. 5, no. 1, pp. 7-10, 1998.

[20] Y. Gao, M. Olivas-Martinez, H. Y. Sohn, H. G. Kim, and C. W. Kim, "Upgrading of low-grade manganese ore by selective reduction of iron oxide and magnetic separation," Metallurgical and Materials Transactions B: Process Metallurgy and Materials Processing Science, vol. 43, no. 6, pp. 1465-1475, 2012.

[21] S. Ghali, M. Eissa, and H. El-Faramawy, "Simulation of austenitic stainless steel oxidation containing nitrogen at temperature range $500^{\circ} \mathrm{C}-800^{\circ} \mathrm{C}$," International Journal of Statistics and Mathematics, vol. 1, no. 3, pp. 24-32, 2014.

[22] S. Ghali and E. A. Mousa, "Analysis of the reduction yield of synthetic iron oxide sinter reduced by $\mathrm{H}_{2}$ at $900-1100^{\circ} \mathrm{C}$ using factorial design approach," Steel Grips, August 2014.

[23] E. A. Mousa and S. Ghali, "Factorial design analysis of reduction of simulated iron ore sinter reduced with CO gas at 1000$1100^{\circ}$ C," Ironmaking \& Steelmaking, 2014.

[24] A. A. El-Geassy, M. I. Nasr, and E. A. Mousa, "Influence of manganese oxide and silica on the morphological structure of hematite compacts," Steel Research International, vol. 81, no. 3, pp. 178-185, 2010.

[25] H. W. Gudenau, D. Senk, A. Babich et al., "Sustainable development in iron- and steel research, $\mathrm{CO}_{2}$ and wastes," ISIJ International, vol. 44, no. 9, pp. 1469-1479, 2004.

[26] I.-H. Jung, Y.-B. Kang, S. A. Decterov, and A. D. Pelton, “Thermodynamic evaluation and optimization of the $\mathrm{MnO}-\mathrm{Al}_{2} \mathrm{O}_{3}$ and $\mathrm{MnO}-\mathrm{Al}_{2} \mathrm{O}_{3}-\mathrm{SiO}_{2}$ systems and applications to inclusion engineering," Metallurgical and Materials Transactions B, vol. 35, no. 2, pp. 259-268, 2004. 

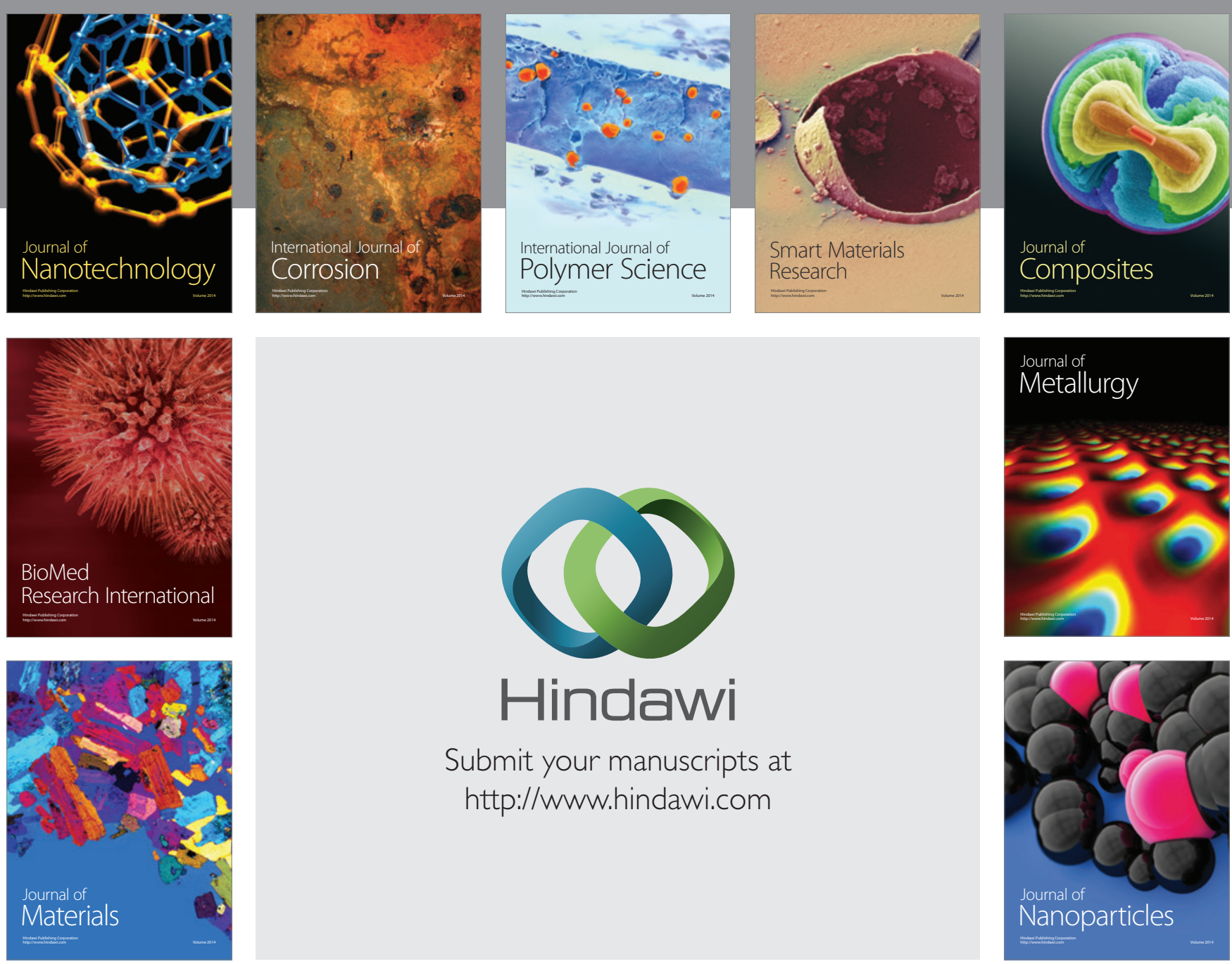

Submit your manuscripts at http://www.hindawi.com
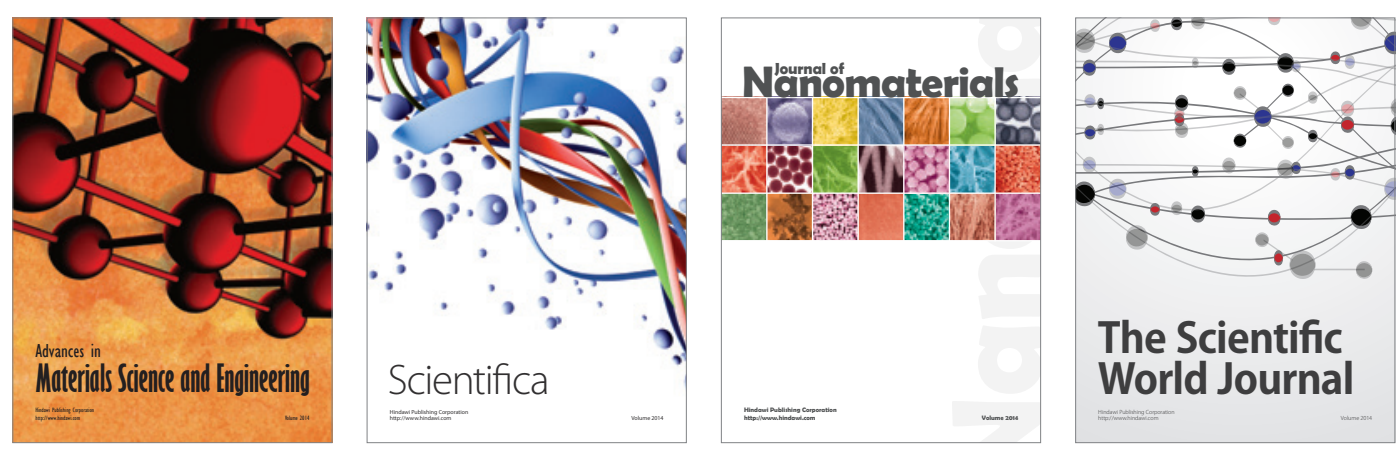

\section{The Scientific World Journal}
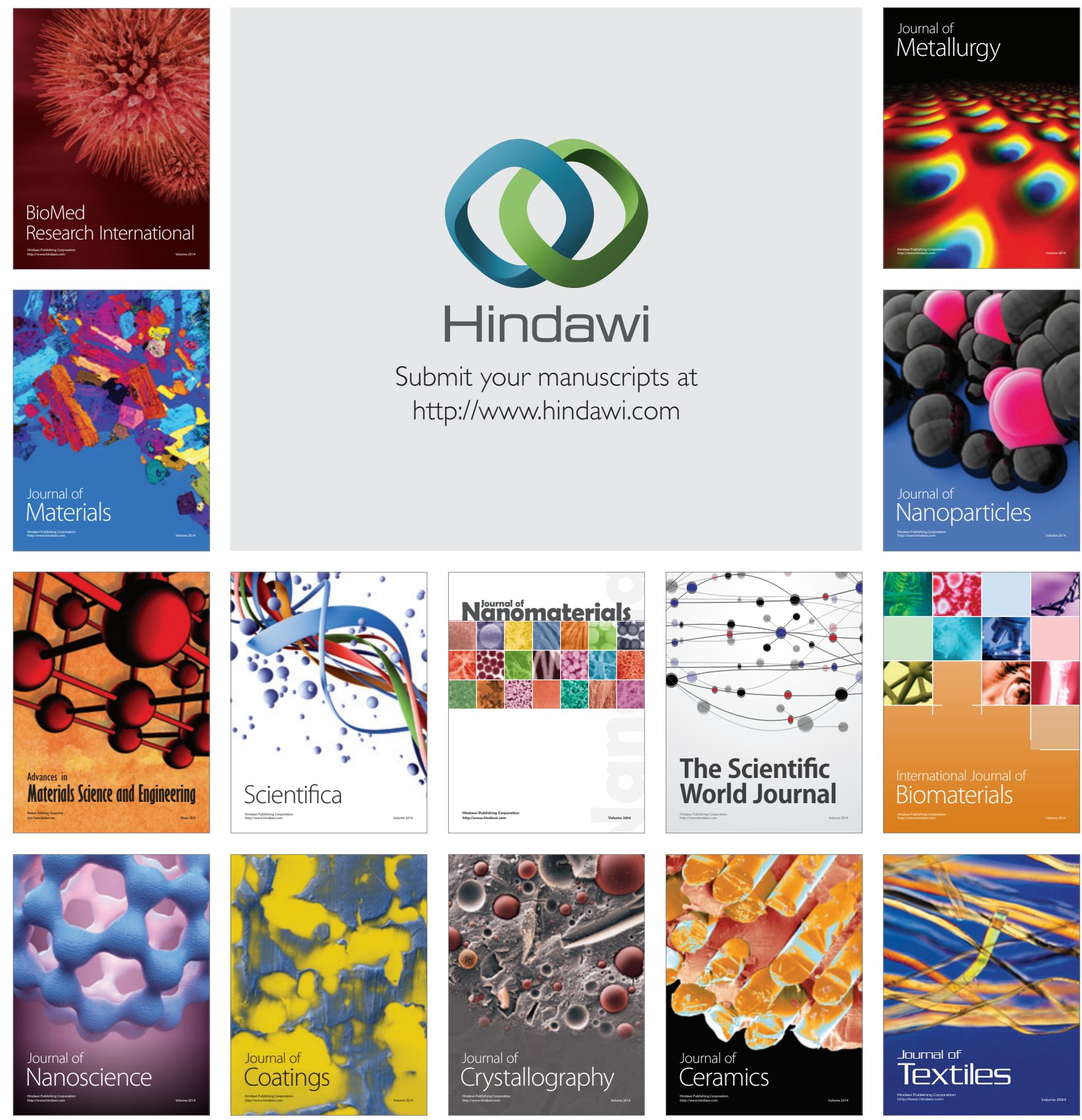